Journal of English Language Teaching and Applied Linguistics

ISSN: 2707-756X

DOI: $10.32996 /$ jeltal

Journal Homepage: www.al-kindipublisher.com/index.php/jeltal

JELTAL

\title{
English Language Learning Experience Among Iban Secondary ESL learners in A Rural Area
}

\author{
Sandra Balentia Engkasan 18 (D) $\triangle$ and Hamidah Yamat ${ }^{2} 8$ (D) \\ ${ }^{1}$ Faculty of Education, Universiti Kebangsaan Malaysia, Malaysia \\ ${ }^{2}$ Associate Professor, Faculty of Education, Universiti Kebangsaan Malaysia, Malaysia
}

$\triangle$ Corresponding Author: Sandra Balentia Engkasan, E-mail: yoesaneun@outlook.com

\author{
ARTICLE INFORMATION \\ Received: February 09, 2021 \\ Accepted: March 14, 2021 \\ Volume: 3 \\ Issue: 3 \\ DOI: 10.32996/jeltal.2021.3.3.8
}

\section{KEYWORDS}

English language learning, Experience, Iban, ESL, Rural Area

\section{ABSTRACT}

English language learning has become a rising topic in the Malaysian Education system as it is unable to develop fluent users among Malaysians. This leads to a question on what are the reasons behind the retardation of Ministry of Education Malaysia regarding the learning of English as a Second Language (ESL) in the country. Hence, this study was carried out to explore English language learning experienced by Iban secondary ESL learners in Saratok, Sarawak, as the ethnic is one of the majority population in Malaysia. This is a case study, and the data were gained through semistructured interview sessions. A set of interview questions comprise of 2 sections were distributed. English language learning and the process involved while acquiring and learning the language at school were explored among three Iban secondary ESL learners. The findings revealed that the Iban learners had a positive attitude towards English language learning by applying various strategies while learning the language in a supportive and convenience classroom's environment. The findings of this study benefit the language teachers as their source of reference in planning their lesson by selecting appropriate approaches and strategies that cater to learners' needs and preferences to facilitate their learning of English language.

\section{Introduction}

Sarawak is the largest state in Malaysia, with a population of 28556000 (Department of Statistic,2020). Sarawak population consists of 27 ethnic groups, and Iban is the major ethnic group in it. (Jabatan Penerangan Malaysia, 2017). The Iban community migrated to Sarawak in the mid-16th century along the Indonesian border route, namely Kapuas Ulu and Batang Ai. The Iban people live in longhouses, their traditional home located mostly in Sarawak's rural and remote area. The longhouse has several "doors" and each "door" occupied by one family. The Iban community in Sarawak is popular with its' formerly tradition known as Head Hunting or 'Ngayau' that demonstrates the Iban male practice of taking and preserving the enemy's head. The Iban community is also well-known for their slogan, which is Agi Idup, Agi Ngelaban, which has the same meaning as 'Still Alive, Still Fighting'.

As one of the states in Malaysia, like the other states, Sarawak has experienced development and changes over time in various sectors, including its educational affair. Thus, the Iban children, as the main community in Sarawak are also not left behind in education as they go to the mainstream school. Due to the long travel distance between school and home, mostly the Iban learners stay in dormitories provided by the school. In school, one of the prominent issues raised among the Iban learners is regarding English language learning, although they learn the language with an average of eleven years of schooling. To demonstrate further, in one primary school in Kapit, one of a rural area in Sarawak, English is the most critical subject tested in a public examination, the Primary School Achievement Test that contributed to the lowest GPMP (Subject Grade Point Average) of English subject. (Chang et al. 2016). The result of GPMP reflected the poor achievement among Iban ESL learners in a rural area as the enrolment statistic in the school was $98 \%$ of Iban primary ESL learners. This result shows a strong connection of Iban

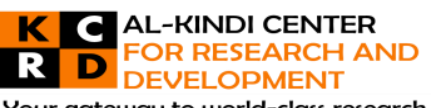

Your gateway to world-class research

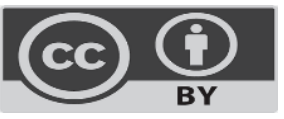

Published by Al-Kindi Center for Research and Development, United Kingdom. Copyright (c) the author(s). This open access article is distributed under a Creative Commons Attribution (CC-BY) 4.0 license 
secondary ESL learners as they pursued their secondary school with the result they obtained from the said test. Therefore, this study focuses on the English language learning experience among Iban secondary ESL learners in a rural area.

By exploring the English language learning among Iban secondary school students at school, the issue of their low level of mastery and proficiency in English can be dealt with wisely. To achieve this study's objective, one research question was formulated: How do the Iban secondary ESL learners experience learning English at school? The following section tackled the previous research which numerous researchers had conducted is discussed to shed more insight into this study. The data from previous studies are analyzed, compared then contrasted.

\section{Literature Review}

Malaysia is a country made up of various races that lead to the multilanguage among Malaysian. Malaysian children raised in the country can speak more than at least three languages, but as English is merely a language for official purposes and language learned in school, pupils in Malaysian schools are varied in terms of experiencing the language. In the Malaysian school setting, there are three groups of pupils in regards to the English language, as illustrated by Iber (2016). The first group is pupils whose English is their first language; meanwhile, the second group was made of ESL learners that easily found in an urban area and this group experienced high exposure to English. Another group is English as a foreign language due to a few reasons and a few of them listed by Iber are poor experience in school as well as their geographical reason. For the third group in the Malaysian school setting, English is their third or fourth language that the pupils mastered after their native and national language. According to the groups outlined by Iber, Iban learners belong to the third group as they are from a rural area and the English language is their third language after the national and native language.

In regards to the Iban learners, as found out by (Agun \& Ahmad, 2016), there are still some people in the longhouse (Iban's traditional house) that are less concerned about their children's academic achievements. Due to this, there are several issues and challenges related to the Iban learners' academic achievement, and multilanguage is one of the issues for them. According to Coluzziet et al. (2013), the non-Malay indigenous majority in Borneo uses various languages such as Bidayuh, Iban, and DusunKadazan. The Iban learners faced hardship to master the English language as they need to imbalance their mastery in three languages: Malay language, English language, and their native language, the Iban language. The three languages are to be covered by them in school in which the Malay Langauge and English Language are compulsory subjects in three public examinations held in Malaysia meanwhile Iban Language is a selective subject. Duka and Aziz (2019) carried out a study on the role of multilingualism in influencing students' English language acquisition in an outskirt Malaysian primary school. They stated that a child is required to speak a native language at home, speak at school the local national language, and learn at least a foreign language as well. This multi-language led to the second or third language fluency may not be as fluent as the first language. As a result, several studies have been performed on the mother tongue of the learners and the method of codeswitching. The Ibans from Year 3 primary students are the participants identified; that is, at the outskirt primary school in Kanowit where they learn standard Iban language, Bahasa Malaysia, and English at school. The results were structured into themes: the level of contact between the three students at school in one day between the three languages (Bahasa Malaysia, Iban language, and English language), the support of home language in learning, and the influence of peers in communicating the English language. Thus, Iban learners face obstructions to disambiguate linguistic aspects within these three main languages in their daily lives. Identifying the issue faced by the said indigenous group, which was dragging between the three languages, many poor language learners cannot use the language accurately, especially in rural areas. Another relevant researcher on Iban's learner in Malaysian school was Chambers and Yunus (2017), who carried out a study on enhancing learners' sentence constructions via "Wheel of Grammar". The research was conducted at SMK Kanowit, with Ibans being the bulk of the 1,313 students. Their observation showed that Malay, Chinese, Bidayuh, Kenyah, Kayan, Melanau, Indian, and Dusun students talked to each other and their teachers in the Iban language. They highlighted this is the factor for poor command of the English language. They have obstacles in forming basic sentences. Secondly, due to insufficient exposure to the language, they face considerable difficulties in scoring good results in the examinations. The research proposed fun element is the key for language to learn involuntarily. Although many language learning solutions had been implemented in Malaysia, such as Strengthen the Malay Language, uphold the English language, and the implementation of the CEFR (Common European Framework Reference) syllabus, the English language proficiency among Iban students still barred them from performing well in the language. This research, in particular, endeavors to find a solution to tackle the problem of Iban learners who struggle in the English language, due to multilanguage that needed to be acquired.

\section{Methodology}

\subsection{Research Design}

Research designs are the type of tools that can be used in the unit analysis of quantitative, qualitative, or mix-method data. (Creswel, 2014, pg 293). Since this study intended to focus English language learning experience by Iban secondary ESL learners 
in a rural area, a case study design was adopted in order for the researcher to see in-depth the learning process that occurred among the Iban learners.

\subsection{Participants of the Study}

In regard of choosing the participants, one of the schools was selected as the researcher works there and it is convenient for the researcher to build a rapport with the participants and English teacher to fulfill the reliability and validity of the research. In order to precisely address the research questions in this study, the researcher determined participants and research sites that can best provide the information. The procedure included putting the sampling procedure in place and deciding on the amount of participation in providing data until the saturation of data was achieved. Due to the rationale as stated previously, purposive sampling was utilized. A set of inclusion criteria was decided by the researcher. The criteria are 1) Iban secondary ESL learners and 2) participants' parents must be of Iban ethnicity. 4 participants involved in this study that comprised of 3 Iban learners and their English teacher. The three Iban learners are represented by pseudonyms names to retain their anonymity.

\subsection{Instrumentation}

The instrument used for this study was an interview protocol constructed from Marijana (2011) and the researcher adapted it from Larsen-Freeman (2000:7). The interview protocol consists of 2 sections: 1) personal info which required participants to answer some demographic questions and their consent in agreeing to participate in the study, part 2) interview protocol on participants' experience learning English at school.

\subsection{Procedure}

Before collecting data, the researcher gets permission from the school principal and the parents to conduct the interview. The interview sessions were held in a convenient setting to promise reliability and validity of data. Participants were then asked to fill in their data on the given handout. Participants had been briefed on the purpose of the research and also highlighted on confidential data. The interview session was recorded with a voice recorder apps on the researcher's smartphone to ensure no response is overlooked.

\subsection{Data Analysis}

The data gained for the semi-structured interview will be analysed with constant comparative analysis which involves transcribing, coding and interpretation. Themes were gathered from emerged categories and codes after the researcher transcribed the participants' responses. The first process is coding which is by reading participants' responses rigorously to enable the researcher to perform categorization. Next, formed codes will be differentiated that is gained from the semistructured interview of three Iban secondary ESL learners in a rural area, their mothers and their English teacher. The codes enable the researcher to representing suitable phenomena as suggested by Punch (2013).

The second process involves the differentiation of codes that will help the researcher to set up few categories. Individual codes generate a conceptualization of the respective interviewed data, but categorization will help the researcher find out similar aspects of each interviewed data and form a meaningful whole in the same group. The function of categorization is to convert raw data to the phase of abstraction. The abstraction phase is done by combining the same aspect and meaning in categories that will then be placed in the same theme. In constant comparative analysis wise, the findings will be tabulated in terms of extracts gained from the interview protocol with Iban language responses then translated to the English language.

\section{Results and Discussion}

\begin{tabular}{|c|c|c|c|}
\hline Participants & Related Questions & Answer & Theme \\
\hline \multirow[t]{4}{*}{ Kumang } & $\begin{array}{l}\text { What do you usually do during } \\
\text { English lessons? }\end{array}$ & $\begin{array}{l}\text { Ha.. macam niru jawapan kawan. } \\
\text { Ha.. It looks like I copied my } \\
\text { friend's answer }\end{array}$ & Strategy - Observe \\
\hline & $\begin{array}{l}\text { How do you know your friend's } \\
\text { answer is correct? }\end{array}$ & $\begin{array}{l}\text { Enda, laban ya nitih logik. } \\
\text { (No. It is based on logic) }\end{array}$ & Strategy - Matching \\
\hline & $\begin{array}{l}\text { Don't you feel shy although you } \\
\text { speak with wrong grammar? }\end{array}$ & $\begin{array}{l}\text { Emm.. enda malu. Laban nya } \\
\text { proses pembelajaran. } \\
\text { (Emm.. I don't feel shy. It is a } \\
\text { learning process) }\end{array}$ & Positive attitude - Confident \\
\hline & $\begin{array}{l}\text { How your teacher teaches you in } \\
\text { class? }\end{array}$ & $\begin{array}{l}\text { Mayuh ngadu kertas soalan. Part } \\
\text { 2. Membetulkan kesalahan. }\end{array}$ & $\begin{array}{l}\text { Examination oriented }- \text { Formal } \\
\text { Grammar }\end{array}$ \\
\hline
\end{tabular}




\begin{tabular}{|c|c|c|c|}
\hline & \multirow[b]{2}{*}{$\begin{array}{l}\text { Do you make any preparation } \\
\text { when you want to say something } \\
\text { in class? }\end{array}$} & $\begin{array}{l}\text { A lot of examination set, Part } \\
\text { 2. (Error correction) }\end{array}$ & \multirow[b]{2}{*}{$\begin{array}{l}\text { Positive attitude - Confident } \\
\text { Learning strategy - Asking the } \\
\text { teacher }\end{array}$} \\
\hline & & $\begin{array}{l}\text { Spontaneous. Walaupun salah, } \\
\text { tanya ya baru betulkah ayatnya? } \\
\text { Spontaneous. Although it is } \\
\text { wrong, I will ask my teacher } \\
\text { either my sentence is correct or } \\
\text { not. }\end{array}$ & \\
\hline & $\begin{array}{l}\text { What kind of homework does your } \\
\text { teacher give you? }\end{array}$ & $\begin{array}{l}\text { Kerja rumah Diary, Essay, } 5 \\
\text { Words Per Day. } \\
\text { Homework. Diary, Essay, } 5 \\
\text { Words Per Day }\end{array}$ & $\begin{array}{l}\text { Homework Pattern - Enrichment } \\
\text { and enhancement }\end{array}$ \\
\hline & $\begin{array}{l}\text { What do you feel about English } \\
\text { subjects in school? }\end{array}$ & $\begin{array}{l}\text { Seronok laban ulih practice jaku } \\
\text { kitai. } \\
\text { It is fun because we can } \\
\text { sharpen our speaking skills. }\end{array}$ & $\begin{array}{l}\text { Classroom's environment - } \\
\text { Supportive }\end{array}$ \\
\hline Rentap & $\begin{array}{l}\text { What do you usually do during } \\
\text { English lessons? }\end{array}$ & $\begin{array}{l}\text { Fokus then enti enda nemu niru } \\
\text { jawapan kawan. Maca buku } \\
\text { Bahasa Inggeris exercise yang } \\
\text { lama. Buku teks jarang la maca } \\
\text { buku teks laban nadai jawapan. } \\
\text { Ninga acara cikgu bejaku. } \\
\text { Sebutan. } \\
\text { I will be focused during the } \\
\text { lesson and if I don't know I } \\
\text { will copy my friend's answer. I } \\
\text { usually refer back to what I } \\
\text { did in my exercise books. I } \\
\text { seldomly refer to the textbook } \\
\text { because there is no answer } \\
\text { provided. I listened to the way } \\
\text { my teacher speaks }\end{array}$ & $\begin{array}{l}\text { Strategy - Observe and assistance } \\
\text { from classmates. }\end{array}$ \\
\hline & $\begin{array}{l}\text { How your teacher teaches you in } \\
\text { class? }\end{array}$ & $\begin{array}{l}\text { Set soalan exam. Part } 2 . \\
\text { Examination set from Part } 2 .\end{array}$ & $\begin{array}{l}\text { Examination oriented }- \text { Formal } \\
\text { Grammar }\end{array}$ \\
\hline & $\begin{array}{l}\text { Do you make any preparation } \\
\text { when you want to say something } \\
\text { in class? }\end{array}$ & $\begin{array}{l}\text { Spontaneous. Aku akan fikir dulu } \\
\text { sebedau ku nanya. Translate ku. } \\
\text { It is spontaneous, but I will } \\
\text { think first before I ask. Then I } \\
\text { will translate the word. }\end{array}$ & $\begin{array}{l}\text { Positive attitude - Confident } \\
\text { Strategy - Translation }\end{array}$ \\
\hline & $\begin{array}{l}\text { What is your opinion about } \\
\text { learning English at school? }\end{array}$ & $\begin{array}{l}\text { Best. Fun. Laban ku minat } \\
\text { English. } \\
\text { I like it and it is fun because } \\
\text { my favorite subject is the } \\
\text { English language. }\end{array}$ & $\begin{array}{l}\text { Classroom's environment } \\
\text { Conducive }\end{array}$ \\
\hline & $\begin{array}{l}\text { What kind of homework does your } \\
\text { teacher give you? }\end{array}$ & $\begin{array}{l}\text { Modul exam, } 5 \text { words per day, } \\
\text { Diary. } \\
\text { Examination set, } 5 \text { Words per }\end{array}$ & $\begin{array}{l}\text { Homework Pattern - Enrichment } \\
\text { and enhancement }\end{array}$ \\
\hline
\end{tabular}




\begin{tabular}{|c|c|c|c|}
\hline & & Day and Diary. & \\
\hline \multirow[t]{5}{*}{ Lulung } & $\begin{array}{l}\text { Did you ever try to copy your } \\
\text { friend's answer? }\end{array}$ & $\begin{array}{l}\text { Kala a. Laban namahal neh. } \\
\text { Panduan sebenar ya. Ukai tek } \\
\text { berniat meniru. Nuan meda } \\
\text { bakatu, oh! Bakanya ku bulih } \\
\text { idea. } \\
\text { I did. I am not sure why I did } \\
\text { it. It is for reference. It is not } \\
\text { my intention to copy my } \\
\text { friend's answers. When I see } \\
\text { their answer, I know how to do } \\
\text { it. That is how I get the idea. }\end{array}$ & Strategy - Observe and matching \\
\hline & $\begin{array}{l}\text { How your teacher teaches you in } \\
\text { class? }\end{array}$ & $\begin{array}{l}\text { Soalan PT3. Focus kepada exam. } \\
\text { PT3 (Form } 3 \text { Assessment) } \\
\text { examination set. Focus on } \\
\text { public examination. }\end{array}$ & Examination oriented \\
\hline & $\begin{array}{l}\text { Do you make any preparation } \\
\text { when you want to say something } \\
\text { in class? }\end{array}$ & $\begin{array}{l}\text { Enti ku nanya, ku tanya terus. } \\
\text { Enti presentation ku sedia skrip. } \\
\text { Translate kadang-kadang. } \\
\text { If I wanted to ask, I asked } \\
\text { spontaneously. But for the } \\
\text { presentation, I prepared a } \\
\text { script. Sometimes I translated } \\
\text { the words. }\end{array}$ & $\begin{array}{l}\text { Positive attitude - Confident } \\
\text { Strategy - Translation }\end{array}$ \\
\hline & $\begin{array}{l}\text { What kind of homework does your } \\
\text { teacher give you? }\end{array}$ & $\begin{array}{l}\text { Ngiga } 5 \text { words per day. Diary. } \\
\text { Finding for } 5 \text { Words per Day } \\
\text { and Diary. }\end{array}$ & $\begin{array}{l}\text { Homework Pattern - Enrichment } \\
\text { and enhancement }\end{array}$ \\
\hline & $\begin{array}{l}\text { What do you feel about English } \\
\text { subjects in school? }\end{array}$ & $\begin{array}{l}\text { Best belajar English ba school. } \\
\text { I like it. It is fun to learn } \\
\text { English at school. }\end{array}$ & School' environment - Conducive \\
\hline Teacher & $\begin{array}{l}\text { What normally happens in your } \\
\text { lesson? }\end{array}$ & $\begin{array}{l}\text { They tried their best to speak in } \\
\text { English with me. They also } \\
\text { participate actively in my class. I } \\
\text { observed they asked their friend } \\
\text { first and then me. They enjoy } \\
\text { being in my class. They look } \\
\text { excited and eager to do } \\
\text { everything. }\end{array}$ & $\begin{array}{l}\text { Positive attitude - Confident and } \\
\text { involuntary learning. } \\
\text { Classroom's environment } \\
\text { Convenience } \\
\text { Strategy - assistance from } \\
\text { classmates and teacher. }\end{array}$ \\
\hline
\end{tabular}

Few themes emerged from the data gained to indicate that the three Iban secondary ESL learners applied various strategies while learning and acquiring the English language at school. They observe their classmates, match their answers with their classmates, and ask for assistance from their teacher and translate. Other than that, the data shows another theme which is a positive attitude among the three Iban secondary ESL learners because they are willing to converse in English with their friends and realized that making a mistake is a learning process. Besides that, it is found out that their classroom environment played important roles by being conducive and supportive for the learners to learn English as they shared the same opinion about excitement learning English at school. These two themes which are language learning strategies and positive attitudes towards ESL learning show that the three lban secondary ESL learners make an initiative to master the language as the theme also in line with their teacher's response. Besides that,

Apart from that, two more themes can be generated from the data are related to the English language teaching exposed to the 
participants. The characteristics of English lessons exposed to the three Iban ESL secondary learners depend on the choice of their teacher as their teacher opted for exam-oriented teaching, enrichment, and enhancement homework pattern as well as formal grammar teaching. The findings found that the homework given to the participants was intended for the enrichment and enhancement of their English learning. Participants were asked to do 5 Words per Day homework because, according to their teacher, she realized that her students are less fond of reading storybooks or English reading materials. By doing so, the teacher can help the participants to enrich their vocabulary register. The participants were also told to write their daily dairy because, according to the teacher she wanted to familiarise the participants with writing exercise which she believes it is beneficial for their writing skills which tested in the public examination. Thus, the dairy is an enhancement tool in English learning among the participants

At the school level, the participants' mastery level in English language learning is only conducted to test their writing and reading skills. For listening and speaking skills, they will only be exposed to listening and speaking activity when the public examinations are just around the corner. This public examination is carried out only once when students are at the end of their lower secondary studies. This means that the Iban learners are rarely exposed to the activity that can enhance their listening and speaking skills. The findings are in line with the findings of the types of homework given by English language teachers to the participants, such as essay writing, grammar, and vocabulary, where these aspects are required in the typical evaluation carried out on them, i.e. writing and reading only. This finding indicates that English language learning among Iban secondary ESL learners in Saratok, Sarawak is more exam-oriented where teachers emphasized more on these two skills as they are tested more frequently in student exams at their school level.

As the Iban learners speak in English with their teacher, the finding is in contrast to the finding gained by Chambers and Yunus (2017) in their study. This is because the Iban learners had a positive attitude about their language learning as they believe it is beneficial to enhance their speaking skills. However, Chamber and Yunus highlighted the fun element in language learning that is happened among the Iban learners in this study. The support and convenience of the learning atmosphere in their classroom then lead to the positivity of learning the language.

Since the Iban learners applied translation strategy in their language learning, the finding is in line with studies done by Coluzzi et al. (2013) and Duka and Aziz (2019). Both studies indicated the influence of the mother tongue on English language learning among the Iban learners. The same goes for this study as the three Iban learners had to translate some of the words from their mother tongue to English.

This study also finds out that although the Iban learners did not have any problem with their language learning, they faced insufficient exposure to the language, as found out as well in Iber (2016) study, the term of their teacher's pedagogy. It was found out that their teacher focused on Reading and Writing materials for the Iban learners as their preparation for their Form 3 Assessment Test, as the second important public examination in Malaysian mainstream school.

\section{Conclusion}

Exploring the Iban secondary ESL learning among Iban secondary learners may be one of the researcher's interests as they are among the biggest population in Malaysia. It is a vital sign to explore so that related parties have a better insight into a root caused that leads to low proficiency among them. Thus, Iban ESL learners need to be aware of language learning strategies that can be served as a tool to enhance their engagement in language learning. For instance, as the participants know that they are visual learners, they can maximize and improve their language learning by visual aids such as film, mind maps, diagrams, and charts. Being a second language learner is very difficult for them to have a grasp and strong foundation in English language learning. Nevertheless, these difficulties can be easy if Iban secondary ESL learners are able to change their attitude and motivation in language learning. They need to understand that poor attitude and motivation towards ESL will lead to a lack of interest in learning. This deepens the problem as they may feel that English seems to be unimportant compared to the other subjects.

The teacher needs to implement new interventions on the Iban secondary ESL learners so the teacher can enlighten their difficulties in learning the language and expose them to the various flexible strategies compared to the common one. The teacher needs to increase listening and speaking activity to be embedded in their lesson as Iban secondary ESL learners admitted that they are rarely exposed to the activities and tasks. The teacher also needs to be a role model to Iban ESL learners in secondary education as participants in this study had the perception that they will not learn English without the teacher's presence. This will indirectly enable Iban ESL learners to imitate teachers' success in this language. Administer should guides teachers on school curriculum that need to be emphasized to improve students' performances in all language skills, namely listening, speaking, reading, and writing skills. In regards to this study, speaking and listening skills can be described as neglected, overlooked, or taken for granted by the teacher. In this matter, administrators should come with a solution to bring 
awareness to Iban parents that speaking and listening skills among their children need to be polished at home and make sure their children finish up their writing and reading homework given by the teacher at school.

Likewise, this study should be conducted with a wider scope of the investigation; for example, bigger sample size to enable generalization can be made about Iban ESL learners in secondary education learn English. The nature of this study also can be switched to a quantitative study so that, for instance, the relationship related to language learning between their ethnicity and another ethnic can be compared. According to Mahamod et al. (2015), students' diversities included students' differences in terms of their attitude, emotions, and background. These differences existed as a result of multiculturalism. Thus, by investigating the learning experience of different ethnicities, educationists will get a better insight and equip themselves with new talent to fill the gap due to differences among students. As the educationist competent in differentiated strategy, it will increase the chance for students with various cultures to succeed in executing the educational task.

Funding: This research received no external funding

Acknowledgments: All authors contributed equally to the conception and design of the study.

Conflicts of Interest: The authors declare no conflict of interest.

\section{References}

[1] Agun, D. B. A., \& Ahmad, A. (2016). Living In The Longhouse And Iban Student Academic Achievement: Issues And Challenges. Universiti Kebangsaan Malaysia.

[2] Chambers, G. J., \& Yunus, M. M. (2017). Enhancing Learners' Sentence Constructions via" Wheel of Grammar". Pertanika Journal of Social Sciences \& Humanities, 25(4).

[3] Chang, C. C., Yan, C. F., \& Tseng, J. S. (2012). Perceived convenience in an extended technology acceptance model: Mobile technology and English learning for college students. Australasian Journal of Educational Technology, 28(5).

[4] Coluzzi, P., Riget, P. N., \& Xiaomei, W. (2013). Language vitality among the Bidayuh of Sarawak (East Malaysia). Oceanic linguistics, 52(2), 375-395. Fetters, M. D., Curry, L. A., \& Creswell, J. W. (2013). Achieving integration in mixed methods designs-principles and practices. Health services research, 48(6pt2), 2134-2156.

[5] Cresswell, J. W. 2014. Research Design. California: Sage Publication Ltd.

[6] Department of Statistics Malaysia. (2020). Demographic Statistics Fourth Quarter 2020.

[7] Iber, G. (2014). English language teaching in Malaysia: The case for a dual track English curriculum. Advances in Language and Literary Studies, 5(4), 68-71.

[8] Jabatan Penerangan Malaysia. (2017).

[9] Mahamod, Z., Amir, R., \& Embi, M. A. (2015). Kepelbagaian pelajar dan perbezaan pembelajaran. Dewan Bahasa dan Pustaka.

[10] Matic, M. (2011). The English language learning experience and its impact on the future English language teachers' career. Procedia Social and Behavioral Sciences, 11, 132-135.

[11] Punch, K. F. (2013). Introduction to social research: Quantitative and qualitative approaches. sage. 